\title{
Pengembangan Asesmen Keterampilan Berpikir Kreatif Siswa SMP Negeri 5 Madiun pada Materi Cahaya dan Alat Optik
}

\author{
Kornelia Devi Kristiani $^{1}$, Tantri Mayasari ${ }^{2}$, Erawan Kurniadi ${ }^{3}$ \\ 1,2,3 Program Studi Pendidikan Fisika \\ Universitas PGRI Madiun, Jl. Setiabudi 85 Madiun 63118, (0351) 462986
}

Email: korneliadevikristiani@gmail.com ${ }^{1}$,bu_tantri@yahoo.co.id ${ }^{2}$,erawan.kurniadi@yahoo.co.id ${ }^{3}$

\begin{abstract}
The purpose of this research is developing the assessment of creative thinking skill of SMP Negeri 5 Madiun students in light material and optical asesment. The assessment consists of a number of essay questions that require students' creative thinking skills that are developed using indicators of creative thinking skills such as fluency, flexibility, originality, and elaboration. The development research procedure adapts from the limited Four-D development model that includes Define, Design, and Develop. Selected expert subject (expert) as the validator of students' creative thinking skill assessment. The subjects of the experiment are students of class VIII A SMP Negeri 5 Madiun. Assessment of creative thinking skills involves experts, including creative thinking experts, learning experts, and content physics experts (criticizing the depth and truth of physics matter). Experts validate content, rate products and questionnaire student responses. The result of this research is validation assessment and get expert suggestion as validator, revised and tested again until calculated by CVR and CVI calculation with acquisition of CVR is 1 and CVI is 1 , hence the result of validity about student creative thinking skill declared valid and very appropriate to be used as an assessment of creative thinking skills.
\end{abstract}

Keywords: Assessment, Creative Thinking Skills

\begin{abstract}
Abstrak: Tujuan dari penelitian pengembangan ini yaitu mengembangkan asesmen keterampilan berpikir kreatif siswa SMP Negeri 5 Madiun pada materi cahaya dan alat optik. Assesmen yang dibuat terdiri dari sejumlah soal essay yang menuntut keterampilan berpikir kreatif siswa yang disusun menggunakan indikator keterampilan berpikir kreatif seperti kemampuan berpikir lancar (fluency), luwes (flexibility), orisinil (originality), dan memperinci (elaboration). Prosedur penelitian pengembangan mengadaptasi dari model pengembangan Four-D terbatas yang meliputi Define, Design, dan Develop. Dipilih subyek ahli (expert) sebagai validator asesmen keterampilan berpikir kreatif siswa. Subyek uji coba yaitu siswa kelas VIII A SMP Negeri 5 Madiun. Asesmen keterampilan berpikir kreatif melibatkan para ahli, antara lain ahli berpikir kreatif, ahli pembelajaran, dan ahli konten fisika (mengkritisi dari kedalaman dan kebenaran materi fisika). Para ahli memvalidasi isi, menilai produk dan angket respon siswa. Hasil penelitian ini yaitu asesmen yang telah di validasi dan mendapatkan saran dari ahli (expert) sebagai validator, direvisi dan diujikan kembali hingga dihitung dengan perhitungan CVR dan CVI dengan perolehan CVR sebesar 1 dan CVI sebesar 1, dengan demikian hasil validitas soal keterampilan berpikir kreatif siswa dinyatakan valid dan sangat sesuai untuk dijadikan assesmen keterampilan berpikir kreatif.
\end{abstract}

Kata kunci: Asesmen, Keterampilan Berpikir Kreatif

\section{PENDAHULUAN}

Pada abad 21, ilmu pengetahuan dan teknologi berkembang begitu pesat, hal tersebut menuntut siswa untuk menguasai berbagai keterampilan agar dapat bersaing secara global. NSTA (2011) menyatakan bahwa dalam pendidikan dapat mengembangkan keterampilan abad 21, seperti keterampilan berpikir. Pendidikan mengajarkan siswa cara berpikir yang tepat, serta memberikan informasi yang akurat untuk membawa keterampilan berpikir yang 
benar pada siswa (Bacanlı et al, 2009). Berbagai keterampilan berpikir tersebut merupakan suatu proses dan perilaku siswa yang diintegrasikan untuk mempelajari dan memahami konten materi pembelajaran (Beers, 2011). Sidharta \& Anwar (2007) juga berpendapat bahwa pembelajaran yang memberikan kesempatan kepada siswa untuk memperoleh keterampilan dalam pemecahan masalah akan mewujudkan pengembangan kemampuan berpikir. Keterampilan berpikir yang harus dikembangkan oleh siswa, salah satunya yaitu keterampilan berpikir kreatif. Mengembangkan keterampilan berpikir kreatif di sekolah dilakukan melalui kegiatan yang dapat melatih siswa melaksanakan proses berpikir kreatif. Siswa harus dididik untuk kreatif agar tidak hanya menjadi konsumen pengetahuan tetapi juga mampu menghasilkan pengetahuan baru.

Berpikir kreatif merupakan salah satu tahapan berpikir tingkat tinggi yang diperlukan dalam kehidupan masyarakat, dan manusia selalu dihadapkan pada permasalahan sehingga diperlukan kreativitas untuk memecahkan permasalahan tersebut. Azumardi sebagaimana dikutip oleh Suryosubroto (2009:194) menyatakan bahwa paradigma pendidikan harus dilandasi sistem pembelajaran yang mengajarkan kreatif. Berpikir kreatif berkaitan dengan kemampuan untuk memaknai fenomena. Pendapat lain, Torrance (dalam Fasko, 2001: 320) menyatakan "...when creative learning occurs, such as improved motivation, alertness, curiosity, concentration, and achievement. Thus, creative teaching can enhance learning”. Berpikir kreatif merupakan salah satu keterampilan yang paling penting bagi siswa untuk memperoleh dan mengembangkan sejumlah konteks pembelajaran, memperkaya akuisisi pengetahuan dan keterampilan yang nantinya di perlukan dalam kehidupan profesional (Waite \& Bromfield, 2002: 367).

Keterampilan berpikir kreatif yang dapat mewujudkan kreativitas sungguh sangat penting dan diperlukan bangsa saat ini dalam rangka mewujudkan kehidupan masyarakat yang lebih baik mampu menciptakan penemuan-penemuan baru dari hasil sumbangan pemikiran kreatifnya. Keterampilan berpikir seperti keterampilan berpikir kreatif menjadi hal yang sangat penting dalam dunia pendidikan. Kreativitas adalah hasil belajar dalam kecakapan kognitif, sehingga untuk menjadi kreatif dapat dipelajari melalui proses belajar mengajar (Slameto, 2003:138). Pembelajaran merupakan suatu upaya yang dilakukan untuk memperoleh kompetensi atau berupa kemampuan, keterampilan dan sikap yang diperlukan dalam melakukan suatu pekerjaan.

Pendidikan saat ini menuntut siswa untuk memiliki keterampilan berpikir kreatif. Dalam kurikulum saat ini disebutkan bahwa standar kompetensi lulusan peserta didik tingkat SMP pada dimensi keterampilan menyatakan siswa harus memiliki kemampuan berpikir dan bertindak kreatif, produktif, kritis, mandiri, kolaboratif, dan komunikatif (Kementrian Pendidikan dan Kebudayaan, 2016). Terlihat bahwa aspek kreativitas menjadi hal penting yang perlu ditanamkan dalam setiap pembelajaran. Mengingat pentingnya kreativitas bagi keberhasilan seseorang, memupuk dan melatih kreativitas peserta didik menjadi agenda tersendiri dalam kurikulum sekolah. Kreativitas merupakan bagian yang tidak terpisahkan dengan berpikir kreatif. Agar menghasilkan suatu yang kreatif sangat perlu dalam pembelajaran di sekolah dikembangkan suatu pembelajaran yang mendukung peningkatan keterampilan berpikir kreatif. Kondisi kurikulum sekarang ini (kurikulum 2013) juga mengharapkan siswa untuk memunculkan kreativitasnya dalam proses pembelajaran.

Atas dasar ini, maka pembelajaran di kelas diharapkan menggunakan model pembelajaran yang menjurus kepada penemuan konsep dan pemecahan masalah dan untuk mengukur pemahaman siswa terhadap materi alat optik perlu dibuat sistem penilaian (asesmen) yang bersifat autentik sehingga mampu memberikan informasi kemampuan siswa secara holistik dan valid. 
Asesmen merupakan komponen penting dalam penyelenggaraan pendidikan. Upaya meningkatkan kualitas pendidikan dapat ditempuh melalui peningkatan kualitas pembelajaran dan kualitas asesmen. Keduanya saling terkait, sistem pembelajaran yang baik akan menghasilkan kualitas belajar yang baik. Kualitas pembelajaran ini dapat dilihat dari hasil asesmen. Selanjutnya, asesmen yang baik akan mendorong guru untuk menentukan strategi mengajar yang baik dan memotivasi siswa untuk belajar yang lebih baik. Oleh sebab itu, dalam upaya peningkatan kualitas pendidikan diperlukan perbaikan asesmen yang diterapkan (Rasyid dan Mansur, 2007).

Kemampuan berpikir kreatif siswa dapat diketahu memberii dengankan asesmen yang telah dirancang sedemikian rupa sesuai dengan ciri-ciri yang terdapat pada klasifikasi kemampuan berpikir kreatif siswa. Dengan demikian, diharapkan siswa nantinya tidak hanya paham mengenai materi yang diajarkan oleh guru saja. Tetapi, mampu juga untuk menerapkan pemikiran kreatifnya itu agar dapat digunakan dalam penyelesaian masalah yang dihadapinya di luar sekolah. Menurut Munandar (2008) Keterampilan berpikir kreatif siswa ini terbagi menjadi 4 macam, yaitu kemampuan berpikir lancar (fluency), kemampuan berpikir luwes (flexibility), kemampuan berpikir orisinil (Originality), kemampuan memperinci (Elaboration). Setiap kemampuan berpikir memiliki ciri-ciri tersendiri yang berbeda antara satu dengan yang lain.

Akan tetapi, keadaan di lapangan menunjukkan bahwa banyak guru yang belum membuat dan menggunakan asesmen tes tertulis yang benar-benar sesuai dalam mengukur indikator pencapaian pembelajaran dan ranah keterampilan berpikir kreatif siswa. Oleh sebab itu, penulis tertarik untuk mengangkat penelitian ini dengan judul "Pengembangan Asesmen Keterampilan Berpikir Kreatif Siswa SMP Negeri 5 Madiun pada Materi Alat Optik".

\section{METODE PENGEMBANGAN}

Penelitian dilakukan di SMP Negeri 5 Madiun, Jawa Timur. Jenis penelitian yang digunakan pada penelitian ini yaitu penelitian dan pengembangan atau Research and Development (R\&D). Prosedur penelitian pengembangan mengadaptasi pada pengembangan perangkat model 4-D (four D Model), yaitu Define, Design, Develop, dan Dissemination. Dalam penelitian ini, penelitian dibatasi sampai pada tahap develop sehingga disebut dengan model pengembangan Four-D terbatas yang meliputi Define, Design, dan Develop.

Adapun 3 tahap model Four-D terbatas, antara lain:

Define, atau pendefinisian ini meliputi dua tahapan yaitu 1) studi lapangan, yang dilakukan untuk mendapat informasi berupa jenis asesmen penilaian fisika yang digunakan disekolah, dan 2) mengkaji sarana prasarana sekolah, dan proses pembelajaran fisika. Studi literatur dilakukan dengan mencari referensi mengenai kriteria pengembangan keterampilan berpikir kreatif serta indikator-indikator keterampilan berpikir kreatif.

Design: diawali dengan menyusun kisi-kisi soal, menyusun soal, menyusun kunci jawaban, dan validasi desain yang melibatkan para ahli, antara lain ahli berpikir kreatif, ahli pembelajaran, dan ahli konten fisika (mengkritisi dari kedalaman dan kebenaran materi fisika). Setelah divalidasi, asesmen penilaian mengalami beberapa kali revisi untuk memperbaiki asesmen penilaian yang dikembangkan sehingga layak untuk diujicobakan di kelas uji coba. Perbaikan dan penyempurnaan asesmen penilaian dilakukan dengan arahan, bimbingan serta masukan dari validator.

\section{Develop:}

Tahap pengembangan dilakukan dengan uji kualitas asesmen yakni dengan menguji validitas soal yang telah di validasi oleh ketiga validator dengan menggunakan perhitungan Content Validity Ratio (CVR) sebagai berikut: 
Keterangan:

$$
C V R=\frac{N e-\frac{N}{2}}{\frac{N}{2}}
$$

$\begin{array}{ll}\text { CVR } & \text { : Content Validity Ratio } \\ \mathrm{Ne} & \text { : Validator yang setuju } \\ \mathrm{N} & \text { : Jumlah Validator }\end{array}$

Dari hasil perhitungan $C V R$ diatas, akan diperoleh Content Validity Index (CVI) sebagai berikut:

Keterangan:

$$
C V I=\frac{\sum C V R}{\text { Jumlah Soal }}
$$

CVI : Content Validity Index

Kategori $C V I$ akan disajikan dalam bentuk tabel sebagai berikut:

Tabel 1. Katagori $C V I$

\begin{tabular}{cc}
\hline Rentang & Kategori \\
\hline $0-0,33$ & Tidak Sesuai \\
\hline $0,34-0,67$ & Sesuai \\
\hline $0,68-1$ & Sangat Sesuai \\
\hline
\end{tabular}

Asesmen dinyatakan valid oleh pakar, kemudian diujicobakan pada skala terbatas yang melibatkan 6 siswa di sekolah tersebut. Hasil uji coba skala terbatas kemudian direvisi untuk mendapatkan asesmen penilaian yang lebih baik yang kemudian diujicobakan pada skala besar di kelas. Hasil analisis uji coba skala besar didapatkan asesmen penilaian final, kemudian diimplementasikan di kelas VIII A SMP Negeri 5 Madiun. Semua sampel diambil secara sampling purposive.

Tahap pendefinisian, diperoleh data yang meliputi jenis dan kualitas asesment penilaian yang digunakan di sekolah, kondisi sekolah dan proses pembelajaran fisika. Pada tahap pengembangan, data yang terkumpul adalah pengaruh implementasi asesmen penilaian keterampilan berpikir kreatif terhadap hasil belajar pada materi cahaya dan alat optik dan ketercapaian efektivitas serta kepraktisan asesmen penilaian. Data tersebut dikumpulkan dengan menggunakan asesmen penelitian yang berupa lembar validasi ahli, lembar angket, lembar aktivitas siswa, tes essay keterampilan berpikir kreatif. Data kualitatif diolah dengan menggunakan tenik penjumlahan sederhana kemudian dilakukan kategorisasi. Validitas soal tes dihitung dari validasi ahli, dengan perhitungan $C V R$ dan $C V I$. Efektivitas asesmen dapat dilihat dari peningkatan keterampilan berpikir kreatif siswa.

\section{HASIL DAN PEMBAHASAN}

Pengembangan asesmen penilaian keterampilan berpikir kreatif dalam hal ini mengacu pada model pengembangan Four-D terbatas yang terdiri dari (1) Define atau pendefinisian dengan melakukan studi pendahuluan yang meliputi studi lapangan dan studi literatur; (2) Design atau desain produk diawali dengan menyusun kisi-kisi soal, menyusun soal, menyusun kunci jawaban, dan validasi desain; (3) Develop atau pengembangan dimulai dari tahap pra uji coba, uji coba skala terbatas, dan uji coba skala luas.

Pada tahap define atau pendefinisian, dilakukan wawancara dengan guru mata pelajaran IPA dan observasi kelas di SMP Negeri 5 Madiun dengan hasil asesmen penilaian yang digunakan masih mengukur aspek kognitif. belum didapatkan data tentang jenis asesmen penilaian keterampilan berpikir kreatif tepatnya materi cahaya dan alat optik di SMP. 
Asesmen keterampilan berpikir kreatif dibuat berdasarkan indikator keterampilan berpikir kreatif antara lain kemampuan berpikir lancar (fluency), kemampuan berpikir luwes (flexibility), kemampuan berpikir orisinil (Originality), kemampuan memperinci (Elaboration). Asesmen yang berorientasi pada keterampilan berpikir dikembangkan berdasarkan data penelitian pendahuluan tentang asesmen yang ada di lapangan, karakter siswa, kondisi sekolah, tinjauan dari penelitian-penelitian yang relevan, dan tinjauan kebijakan-kebijakan pemerintah tentang orientasi pendidikan nasional, serta mempertimbangkan kemajuan ilmu pengetahuan, dan teknologi. Asesmen keterampilan berpikir kreatif yang dikembangkan mengadaptasi pada indikator keterampilan berpikir kreatif. Keterampilan berpikir kreatif peserta didik dapat dilihat dari perilaku peserta didik dalam kegiatan pembelajaran. (Munandar, 2009) menyatakan bahwa perilaku peserta didik yang termasuk dalam keterampilan kognitif kreatif dapat dijabarkan sebagai berikut:

Tabel 2. Perilaku Peserta Didik dalam Keterampilan Kognitif Kreatif

\begin{tabular}{|c|c|c|}
\hline No. & Perilau Peserta didik & Arti \\
\hline \multirow[t]{2}{*}{1} & Berpikir Lancar (fluency) & $\begin{array}{lr}\text { a) } & \begin{array}{l}\text { Menghasilkan } \\
\text { jawaban/gagasan }\end{array} \\
& \text { belevan; }\end{array}$ \\
\hline & & b) Arus pemikiran lancar; \\
\hline \multirow[t]{3}{*}{2} & Berpikir Luwes (fleksibel) & $\begin{array}{l}\text { a) Menghasilkan gagasan- } \\
\text { gagasan yang seragam; }\end{array}$ \\
\hline & & $\begin{array}{l}\text { b) Mampu mengubah cara atau } \\
\text { pendekatan; }\end{array}$ \\
\hline & & $\begin{array}{l}\text { c) Arah pemikiran yang } \\
\text { berbeda; }\end{array}$ \\
\hline 3 & Berpikir Orisinal (Originality) & $\begin{array}{l}\text { Memberikan jawaban yang tidak } \\
\text { lazim, yang lain dari yang lain, yang } \\
\text { jarang diberikan kebanyakan orang; }\end{array}$ \\
\hline \multirow[t]{3}{*}{4} & Berpikir Terperinci (Elaboration) & $\begin{array}{l}\text { a) Mengembangkan, } \\
\text { menambah, memperkaya } \\
\text { suatu gagasan; }\end{array}$ \\
\hline & & b) Memperinci detail-detail; \\
\hline & & c) Memperluas suatu gagasan \\
\hline
\end{tabular}

Tahap terakhir define yaitu perumusan tujuan pembelajaran yang digunakan untuk dasar pengembangan asesmen keterampilan berpikir kreatif.

Pada tahap design atau desain peneliti melakukan penentuan jadwal penelitian pengembangan yaitu selama 4 bulan, selanjutnya penentuan expert atau ahli yaitu 3 ahli sekaligus sebagai validator, 6 orang siswa ujicoba kelas kecil, dan 32 siswa kelas VIII A ujicoba kelas besar. Spesifikasi desain asesmen penilaian keterampilan berpikir kreatif mata pelajaran IPA pada materi Cahaya dan Alat Optik dibuat dengan teknik tes yaitu berupa tes tertulis yang dilengkapi dengan rubrik penilaian yaitu indikator keterampilan berpikir kreatif. Diawali dengan menyusun kisi-kisi soal. Di dalam kisi-kisi soal terdapat soal berpikir kreatif dan contoh jawabannya, indikator dari soal tersebut, jawaban siswa yang dapat diidentifikasi, skor, dan catatan. Selanjutnya ialah menyusun soal, menyusun kunci jawaban, dan validasi desain yang melibatkan para ahli, antara lain ahli berpikir kreatif, ahli pembelajaran, dan ahli konten fisika (mengkritisi dari kedalaman dan kebenaran materi fisika). Setelah divalidasi, asesmen penilaian mengalami beberapa kali revisi untuk memperbaiki asesmen penilaian yang dikembangkan sehingga layak untuk diujicobakan di kelas uji coba. Perbaikan dan penyempurnaan asesmen penilaian dilakukan dengan arahan, bimbingan serta masukan dari 
validator. Setelah divalidasi, asesmen dihitung dengan perhitungan $C V R$ dan $C V I$. Perhitungan $C V R$ mendapatkan hasil sebesar 1 dan perhitungan $C V I$ mendapatkan hasil sebesar 1, Sehingga asesmen keterampilan berpikir kreatif ini termasuk dalam kategori valid dan sangat sesuai. Hasil validasi soal keterampilan berpikir kreatif dapat dilihat pada tabel berikut ini:

Tabel 3. Hasil Validasi Soal Keterampilan Berpikir Kreatif

\begin{tabular}{cccl}
\hline No. & $\begin{array}{c}\text { Hasil } \\
\text { Validasi }\end{array}$ & Keputusan & \multicolumn{1}{c}{ Keterangan } \\
\hline 1 & Valid & $\begin{array}{c}\text { Digunakan, } \\
\text { dengan Revisi }\end{array}$ & $\begin{array}{l}\text { Ketiga validator menyetujui soal tersebut, dengan revisi mengganti } \\
\text { materi pada soal. Selanjutnya diganti dengan materi perkembangan } \\
\text { kamera. Dari masa ke masa. }\end{array}$ \\
\hline 2 & Valid & $\begin{array}{c}\text { Digunakan } \\
\text { dengan Revisi }\end{array}$ & $\begin{array}{l}\text { Ketiga validator menyetujui soal tersebut, direvisi dengan mengganti } \\
\text { soal yang berkaitan dengan materi kamera. }\end{array}$ \\
\hline 3 & Valid & Digunakan & Ketiga validator menyetujui soal tersebut \\
\hline 5 & Valid & $\begin{array}{c}\text { Digunakan, } \\
\text { dengan Revisi }\end{array}$ & $\begin{array}{l}\text { Ketiga validator menyetujui soal tersebut, direvisi dengan menggati } \\
\text { pertanyaan yaitu membuat desain produk yang berkaitan dengan alat } \\
\text { optik. }\end{array}$ \\
\hline 5 & Valid & Digunakan & Ketiga validator menyetujui soal tersebut \\
\hline
\end{tabular}

Pada tahap develop atau pengembangan dilakukan uji kelas kecil kepada 6 siswa terpilih. Pada uji kelas kecil soal tes diberikan dan mendapatkan hasil yang kurang memuaskan sehingga dilakukan revisi terhadap soal untuk perbaikan nilai siswa yang mengerjakan soal keterampilan berpkir kreatif, lalu dilanjutkan pada ujicoba kelompok besar. Pada uji kelas besar 5 soal tes dinyatakan valid karena terdapat peningkatan terhadap hasil uji kelas kecil dan uji kelas besar yang dapat dilihat melalui gambar grafik yang lebih jelasnya untuk keterampilan berpikir kreatif siswa melaui hasil rata-rata tiap indikator keterampilan berpikir kreatif siswa berikut:

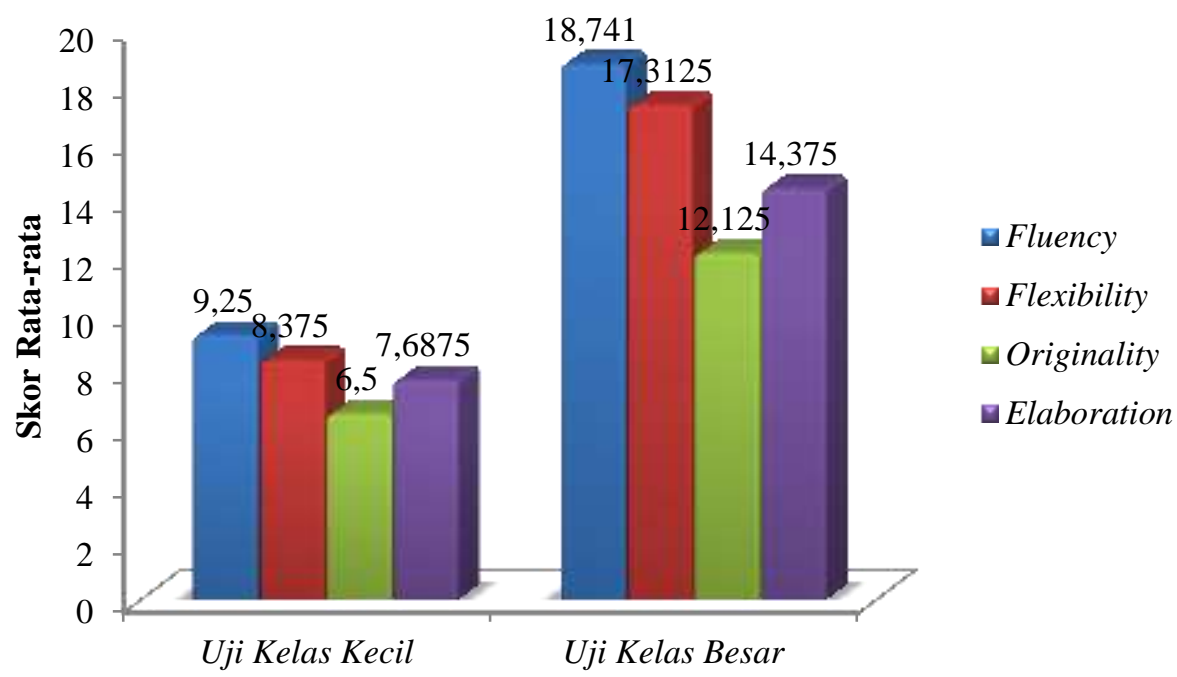

Gambar 1. Hasil Berpikir Kreatif Siswa Tiap Indikator

Dengan demikian dapat dikatakan bahwa 5 soal pada tes yang dikembangkan layak digunakan guru sebagai salah satu alternatif penilaian keterampilan berpikir kreatif siswa pada mata pelajaran IPA terpadu. 


\section{KESIMPULAN DAN SARAN}

Hasil penelitian pengembangan ini berupa seperangkat asesmen penilaian keterampilan berpikir kreatif yang terdiri atas asesmen soal dan rubrik penilaian. asesmen penilaian yang dikembangkan mencakup empat komponen berpikir kreatif yaitu kemampuan berpikir lancar (fluency), kemampuan berpikir luwes (flexibility), kemampuan berpikir orisinil (Originality), kemampuan memperinci (Elaboration).

Nilai validitas dari asesmen penelitian yang berupa tes dinyatakan valid melalui perhitungan CVR dan CVI. Nilai validitas dari tes dinyatakan valid sebelum digunakan dengan hasil perhitungan CVR sebesar 1 dan CVI sebesar 1, Sehingga termasuk dalam kategori valid dan sangat sesuai sebagai asesmen penilaian keterampilan berpikir kreatif.

\section{DAFTAR PUSTAKA}

Bacanl1, H., Dombayc1, M. A., Demir, M., \& Tarhan, S. 2011. Quadruple thinking: Creative thinking. Procedia-Social and Behavioral Sciences, 12, 536-544.

Beers, S. 2011. 21st Century Skills : Preparing Students For Their Future. Diakses dari http://www.yinghuaacademy.org/wpcontent/uploads/2014/10/21st_century_skills.pdf

Fasko Daniel. (2001). Education and creativity. Creativity Research Journal by 2000-2001, Vol. 13, Nos. 3 \& 4, 317327 Munandar. 2008. Pengembangan Kreativitas Anak Berbakat. Jakarta: Rineka Cipta

Munandar, U. (2009). Pengembangan Kreativitas Anak Berbakat. Jakarta: Rineka Jaya.

National Science Teacher Association. 2011. Quality Science Education and $21^{\text {st }}$ Century Skills. Diakses dari http://www.nsta.org/about/positions/21stcentury.aspx

Rasyid, H. dan Mansur. 2007. Penilaian Hasil Belajar. Bandung: Wacana Prima

Slameto. 2003. Belajar dan Faktor-Faktor Yang Mempengaruhinya. Jakarta: Rineka Cipta

Suryosubroto. 2009. Proses Belajar Mengajar di Sekolah. Jakarta: Rineka Cipta

Waite S. \& Bromfield C.(2002). Promoting creative thinking through the use of ICT.Graduate School of Arts and Education and Rolle School of Education. University of Plymouth. Journal of Computer Assisted Learning (2002) 18, 367378 s. 